\title{
MAKNA BUAH ROH DALAM GALATIA 5:22-23
}

Minggus Dilla

minggusdilla@sttab.ac.id

\begin{abstract}
The fruit of the Spirit is the most important part in the life of a believer. Through the Fruit of the Spirit the believer can show his true self. But the understanding of the Fruit of the Spirit is still not widely known by many Believers. Therefore through this article believers can have an understanding of what the fruit of the Spirit is and its meaning in its relation to daily life.
\end{abstract}

Keywords: $\quad$ Meaning, Fruit of the Spirit, Galatians.

\begin{abstract}
Abstraksi: $\quad$ Buah Roh merupakan bagian terpenting dalam kehidupan orang percaya. Melalui Buah Roh orang percaya dapat menunjukkan jati dirinya. Namun pemahaman tentang Buah Roh masih belum banyak diketahui oleh banyak orang Percaya. Oleh karena itu melalui artikel ini orang percaya dapat memiliki pemahaman tentang apa itu buah Roh dan pemaknaannya dalam relasinya dengan kehidupan sehari-hari.
\end{abstract}

Kata Kunci: Makna, Buah Roh, Galatia.

\section{PENDAHULUAN}

Melalui Galatia 5:22-23, Paulus memberitahu kita, "Tetapi buah Roh ialah: kasih, sukacita, damai sejahtera, kesabaran, kemurahan, kebaikan, kesetiaan, kelemahlembutan, penguasaan diri." Buah Roh Kudus itu hasil karya Roh Kudus dalam kehidupan orang Kristen. Alkitab menyatakan bahwa setiap orang menerima Roh Kudus ketika dia percaya kepada Yesus Kristus (Roma 8:9; 1 Korintus 12:13, Efesus 1:13-14). Salah satu tujuan utama datangnya Roh Kudus ke dalam hidup orang-percaya itu untuk mengubah kehidupan. Karya Roh Kudus menyesuaikan kita dengan gambar Kristus, membuat kita menjadi semakin serupa denganNya. Buah Roh Kudus berlawanan dengan perbuatan natur dosa seperti yang ditulis Paulus di Galatia 5:19-21. "Perbuatan daging telah nyata, yaitu: percabulan, kecemaran, hawa nafsu, penyembahan berhala, sihir, perseteruan, perselisihan, iri hati, amarah, kepentingan diri sendiri, percideraan, roh pemecah, kedengkian, kemabukan, pesta pora dan sebagainya. Terhadap semuanya itu kuperingatkan kamuseperti yang telah kubuat dahulu - bahwa barangsiapa melakukan hal-hal yang demikian, ia tidak akan mendapat bagian dalam Kerajaan Allah."1

\footnotetext{
${ }^{1}$ https://www.gotquestions.org/Indonesia/buah-Roh.html, online Januari 2016
} 


\section{PENGERTIAN BUAH ROH}

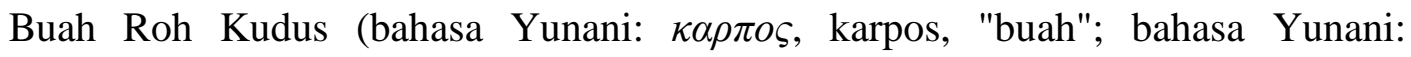
$\pi v \varepsilon v \mu \alpha \tau o \varsigma$, pneumatos, "roh") adalah istilah Alkitab yang merangkum 9 sifat nyata dari hidup Kristen yang sejati menurut rasul Paulus dalam suratnya kepada jemaat di Galatia pasal $5 .^{2}$ Meskipun tertulis ada 9 sifat (atau "atribut"), tetapi istilah aslinya dalam bahasa Yunani untuk "buah" adalah kata tunggal, menegaskan bahwa hanya ada satu macam "Buah", dengan 9 sifat. Di seluruh Alkitab, orang saleh diibaratkan seperti pohon, dan di pasal ini Paulus menjelaskan buah macam apa yang dihasilkan oleh "pohon yang baik" yaitu orang saleh atau orang benar. Buah ini akan dihasilkan oleh mereka yang sungguhsungguh bertobat, yang menjadi pengikut sejati Yesus Kristus. Sebaliknya, jika seseorang tidak menghasilkan buah ini, ia bukanlah seorang Kristen sejati. ${ }^{3}$

\section{MACAM-MACAM BUAH ROH}

\section{Kasih}

Kasih "agape" menunjukkan kehendak hati yang murah hati dan tidak dapat dikuasai yang selalu menginginkan kebaikan orang lain, tanpa peduli apa yang dilakukan orang itu. Merupakan kasih yang memberi yang diberikan cuma-cuma tanpa mengharapkan balasan dan tidak mempertimbangkan nilai pemberiannya. Agape lebih merupakan suatu pilihan daripada philos, yang merupakan kasih yang kebetulan; dan menunjukkan keinginan daripada emosi. Agape menggambarkan kasih Allah yang tanpa pamrih kepada dunia ini. Kata ini terutama dipakai oleh Paulus dalam suratnya yang pertama kepada jemaat diKorintuspasal 13 menggambarkan pengorbanan, seperti yang dilakukan oleh Yesus Kristus dengan kematiannya di kayu salib untuk menebus dosa manusia, yang tidak memegahkan diri:

Kasih itu sabar; kasih itu murah hati; ia tidak cemburu. Ia tidak memegahkan diri dan tidak sombong. Ia tidak melakukan yang tidak sopan dan tidak mencari keuntungan diri sendiri. Ia tidak pemarah dan tidak menyimpan kesalahan orang lain. Ia tidak bersukacita karena ketidakadilan, tetapi karena kebenaran. Ia menutupi segala sesuatu, percaya segala sesuatu, mengharapkan segala

${ }^{2}$ Dictionary of Irish Architects 1720-1940. Irish Architectural Archive. Diakses tanggal 13 February 2013.

${ }^{3}$ https://id.wikipedia.org/wiki/Buah_Roh_Kudus 
sesuatu, sabar menanggung segala sesuatu. Kasih tidak berkesudahan. ${ }^{4}$

Kata "agape", diterjemahkan dalam Terjemahan Baru sebagai "kasih akan semua orang", dipergunakan oleh rasul Petrus dalam suratnya yang kedua: "Justru karena itu kamu harus dengan sungguh-sungguh berusaha untuk menambahkan kepada imanmu kebajikan, dan kepada kebajikan pengetahuan, dan kepada pengetahuan penguasaan diri, kepada penguasaan diri ketekunan, dan kepada ketekunan kesalehan, dan kepada kesalehan kasih akan saudara-saudara, dan kepada kasih akan saudara-saudara kasih akan semua orang." 5

\section{Sukacita}

Kata Yunani untuk "sukacita" adalah chara, yang berasal dari kata charis, yaitu kata Yunani untuk "rahmat" (lang-en|grace\}\}). Dalam kaitan ini, "sukacita" (chara) dihasilkan oleh "rahmat" (charis) Allah. Jadi 'sukacita' ini bukan kebahagiaan manusia yang sesaat saja, melainkan 'sukacita sejati' yang bersumber dari Khalik kudus. Merupakan ekspresi dari Roh yang berkembang paling bagus pada waktu kesusahan. Misalanya, dalam 1 Tesalonika 1:6, jemaat Tesalonika mengalami tekanan berat akibat penganiayaan; tetapi di tengah kesusahan itu, mereka terus mengalami sukacita besar.

Kata chara memberi makna sukacita yang luar biasa karena Roh Kudus bekerja di dalam orang itu. Paulus bahkan menyebutnya "sukacita Roh Kudus". ${ }^{6}$ Di dalam Kitab Nehemia 8:11 tertulis: Sukacita karena TUHAN itulah perlindunganmu! ${ }^{7}$

\section{Damai sejahtera}

"Damai sejahtera" ini merupakan hasil penyandaran pada hubungan dengan Allah. Damai ini adalah keadaan istirahat yang tenang, dihasilkan dari mencari Allah, dan berlawanan dengan keadaan "kacau balau". Kata aslinya dalam bahasa Yunani "eirene" merupakan terjemahan dari kata bahasa Ibrani "syalom" (shalom) yang merupakan ekspresi dari kepenuhan, kesempurnaan atau ketenangan jiwa yang tidak dipengaruhi oleh

\footnotetext{
${ }^{4} 1$ Korintus 13:4-8

${ }^{5}$ 2Petrus 1:5-7

${ }^{6}$ Rick Renner, Sparkling Gems from the Greek

${ }^{7}$ Nehemia 8:10
} 
keadaan ataupun tekanan dari luar. Kata eirene menegaskan kekuatan keteraturan yang berlawanan dengan kekacaubalauan. ${ }^{8}$

\section{Kesabaran}

Kesabaran dalam bahasa Yunani aslinya "makrothumia" terdiri dari dua kata: makros, "panjang," dan thumos "temperamen", yang memberikan makna "kelunakan", "mau menanggung", "panjang sabar", "tabah", "tahan menderita". Juga termasuk dalam kata makrothumia ini kekuatan untuk menanggung aniaya dan perlakuan buruk. Menggambarkan orang yang memiliki kemampuan untuk membalas dendam, tetapi sebaliknya memilih untuk menahan diri.

\section{Kemurahan}

Kemurahan bukan hanya berlaku manis. Orang dapat berbuat murah hati tetapi tidak berperilaku manis. Kelakuan manis lebih bermakna "dapat diterima", sedangkan kemurahan merupakan tindakan yang bermanfaat bagi orang lain tanpa peduli tindakan sebelumnya. Kata christotes merupakan perbuatan baik yang nyata, kelembutan dalam berlaku terhadap yang lain, bersikap penuh rahmat.

\section{Kebaikan}

Bahasa Yunani: agathosune, bahasa Latin: bonitas, bahasa Inggris: goodness.

1. Keadaan atau kualitas untuk bersikap baik

2. Kemuliaan perilaku; kebajikan

3. Perasaan manis, murah hati, ringan tangan

4. Bagian terbaik dari semuanya; Intisari; Kekuatan;

5. Karakter umum yang dikenali dalam kualitas atau perbuatan.

\section{Kesetiaan}

Bahasa Yunani: pistis, bahasa Latin: fides, bahasa Inggris: faithfulness, faith. Kesetiaan adalah mendedikasikan diri kepada sesuatu atau seseorang, misalnya pasangan hidup, atau suatu hal atau suatu kepercayaan/agama. Menjadi setia membutuhkan tekad

${ }^{8}$ Morgan, Elisa. Naked Fruit: Getting Honest about the Fruit of the Spirit. Revell, 2004. ISBN 978-0-8007-1873-2 
pribadi untuk tidak menyimpang jauh dari komitmen atau janji. Tidak selalu mudah untuk menjadi setia. Iman Kristen membutuhkan kepercayaan kepada Allah.

\section{Kelemahlembutan}

Dalam bahasa Yunani, prautes dikenal sebagai "kelembahlembutan". New Spirit Filled Life Bible mendefinisikan kelemahlembutan sebagai "disposisi yang bertemperamen stabil, tenang, seimbang dalam roh, tidak sombong, dan dapat menguasai emosi. Kata ini diterjemahkan sebagai 'kelemahlembutan,' bukan merupakan indikasi kelemahan, melainkan kemampuan menguasai energi dan kekuatan. Orang yang mempunyai kualitas ini mampu mengampuni kesalahan, memperbaiki kekeliruan, dan menguasai jiwanya sendiri dengan baik."

\section{Penguasaan diri}

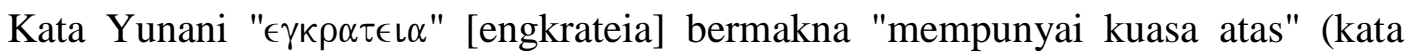
dasar "krat-" seperti pada kata "demokrat", yang berarti "pemerintahan"), atau "kepemilikan atas kelakuan sendiri." Kata yang sama dipergunakan oleh rasul Petrus dalam suratnya yang kedua pasal 1:5-7: "Justru karena itu kamu harus dengan sungguhsungguh berusaha untuk menambahkan kepada imanmu kebajikan, dan kepada kebajikan pengetahuan, dan kepada pengetahuan penguasaan diri, kepada penguasaan diri ketekunan, dan kepada ketekunan kesalehan, dan kepada kesalehan kasih akan saudara-saudara, dan kepada kasih akan saudara-saudara kasih akan semua orang." 9

\section{MAKNA BUAH ROH}

"Buah" Roh yang dipakai di sini berbentuk tunggal, artinya adalah 9 cita rasa ini adalah satu kesatuan yang harus dimiliki oleh orang yang percaya. Buah Roh yang dihasilkan di dalam kita bukanlah "sembilan buah yang berbeda", tapi satu "buah" tunggal diwujudkan dalam sembilan kualitas yang berbeda. Ini mengingatkan kita bahwa Roh Kudus menghasilkan buah-Nya dalam diri kita secara keseluruhan - tidak ada musim buah "kasih", terus buah "sukacita" adalah musim berikutnya, kemudian "perdamaian" musim berikutnya, dan seterusnya. ${ }^{10}$ Kesembilan karakter buah Roh itu dapat dikelompokkan

\footnotetext{
${ }^{9}$ Longman, Robert Jr. "Self-Control." Web: 19 Oct 2010

${ }^{10}$ F.W. Dellistone, The Power Of Simbol, (London: SCM Press, 1986), 55
} 
menjadi 3: pertama Karakter ini berhubungan dengan Allah (Kasih, Sukacita, Damai sejahtera). Kedua, karakter yang berhubungan dengan sesama (Kesabaran, Kemurahan, Kebaikan). Ketiga, karakter yang berhubungan dengan diri sendiri (Kesetiaan, Kelemahlembutan, Penguasaan diri/Kontrol diri). ${ }^{11}$

\section{Karakter Yang Berhubungan Dengan Allah}

Kasih (Agape) adalah tindakan mencari kebaikan tertinggi bagi orang lain. Kasih itulah yang Allah curahkan bagi kita (Rom 5: 5). Kasih dalam Kristus yang "melampaui pengetahuan" (Ef 3: 16-19). Itulah sebabnya pekerjaan Roh Kudus di dalam diri orang percaya harus menghasilkan cinta satu sama lain (1 Yoh 4: 10-11, 16, 21). Karena kita "dipimpin oleh Roh" akan Ia akan menghasilkan buah CINTA di dalam hidup kita.

Bersukacitalah (chara) merupakan sebuah panggilan untuk menjadikan sukacita sebagai sebuah gaya hidup. Entah kita berada dalam situasi yang menggembirakan atau merugikan. Kita harus terus bersukacita. Sukacita Kristen adalah hasil dari sebuah teologi yang mendalam bahwa Allah mengendalikan segala sesuatu untuk kebaikan dan kemuliaan-Nya sendiri dan juga demi kebaikan orang-orang yang mengasihi Dia, dan dengan demikian mereka harus tetap bersukacita tidak peduli bagaimanapun keadaannya. Tuhan adalah sumber sukacita yang tak habis-habisnya.

Damai sejahtera (Eireine). Suasana aman, tentram dan damai sejahtera dalam kehidupan sebenarnya dicari oleh manusia disepanjang zaman di manapun juga. Damai sejahtera yang sejati, tidak bisa diukur oleh uang, rumah, mobil atau apa saja. Damai sejati adalah anugerah Tuhan, "Damai sejahteraKu, Kuberikan kepadamu dan apa yang Kuberikan tidak seperti yang diberikan oleh dunia kepadamu." Yoh.14:27. Damai sejahtera ini adalah lahir dari keyakinan akan kesempurnaan pemeliharaan Tuhan dalam setiap detail hidup kita. Dengan demikian, tidak ada peristiwa apapun juga yang sanggup mencuri damai sejahtera umat percaya.

\section{Karakter Yang Berhubungan Dengan Sesama}

Dalam hubungan dengan sesama memang dibutuhkan kesabaran (makrothumia). Mokrothumia punya pengertian panjang sabar dan tekun. Panjang sabar adalah memiliki kualitas pengendalian diri yang baik dalam menghadapi provokasi. Allah adalah pribadi

\footnotetext{
${ }^{11}$ http://rec.or.id/article_448_Buah-buah-Roh-(Galatia-5:22-26), Online Januari 2016
} 
yang memiliki karakter ini secara sempurna. Karena Ia panjang sabar, memungkinkan untuk kita memiliki keselamatan! (2Ptr 3:15) dan bertobat! ( Ro 2: 4). Ini adalah dasar bagi orang percaya untuk saling mengasihi dan mengusahakan kebaikan orang lain.

Karakter yang berikut adalah Kemurahan (khrestotes). Karakter ini berarti kebaikan yang dipenuhi dengan kemurahan hati. Khrestotes membuat kita bisa bersikap baik dan murah hati terhadap sesamanya yang membutuhkan, bahkan termasuk kepada mereka yang tidak menyenangkan. Kita sendiri memang sulit melakukan hal ini; tetapi Roh Kudus yang tinggal di dalam kita memampukannya. ${ }^{12}$

Kesabaran dan kemurahan tidak lengkap bila belum ada kebaikan (agathosune). Agathosune berarti kebaikan yang mengandung unsur memperbaiki dan mendisiplin agar orang lain lebih baik. Menurut William Barclay, Agathosune berarti kebaikan dalam pengertian yang luas, yaitu "kebajikan yang tersedia dalam segala perkara". Di dalamnya terkandung unsur marah dan disiplin. Barclay menjelaskan bahwa Yesus menunjukkan agathosune (kebaikan) ketika Ia mengadakan pembersihan di Bait Allah serta mengusir mereka yang menjadikan tempat itu seperti pasar; tetapi Ia menunjukkan khrestotes (kemurahan) kepada perempuan berdosa yang meminyaki kaki-Nya. Kasih orang Kristen adalah kasih yang mengusahakan kebaikan orang lain. Tindakan kasih yang tidak mengandung disiplin tidak akan menghasilkan kebaikan.

\section{Karakter Yang Berhubungan Dengan Karakter Diri Sendiri}

Yang pertama dari kualitas ini adalah "kesetiaan" (Pistis). kata ini di dalam teks yang lain diterjemahkan "iman". Tapi di teks ini, pistis diterjemahkan "kesetiaan" - yaitu, kejujuran dan integritas dalam tindakan kita, dan komitmen dan tanggung jawab kita. Karakter ini merupakan implikasi dari kesadaran bahwa kita memiliki Allah yang Maha Tahu, Maha Melihat. Karena semua tindakan kita, pikiran kita, dan motif kita berada di bawah pengamatan konstan Bapa Sorgawi maka kita harus memiliki karakter setia. ${ }^{13}$

Kualitas kedua berkaitan dengan diri batin kita adalah "kelembutan" Mayoritas bahasa Inggris menerjemahkan lemah lembut (Praus) dengan "meek". Kata ini digunakan 4 kali dalam PB di (Mat 5: 5; 11:29; 21: 5; 1 Pet 3: 4). Dalam Yunani Klasik kata ini

\footnotetext{
${ }^{12}$ M.E. Duyverman, M.E, Pembingbing Ke Dalam Perjanjian Baru,(Jakarta: BPK. Gunung Mulia, 2011), 152

${ }^{13}$ Enns, Paul, The Moody Hanbook Of Thelogy,(Malang: Literatur SAAT, 2006), 85
} 
digunakan untuk menjinakkan anjing, obat yang menenangkan, suara yang lembut atau angin yang sepoi-sepoi. Kelemahlembutan adalah sikap hati di mana ia menyerahkan masalahnya dibawah kontrol Allah, sehingga ia dimampukan untuk tetap bersikap lembut.

Akhirnya, kualitas terakhir dalam kategori ini adalah "pengendalian diri". Mayoritas versi bahasa Inggris menerjemahkan "self control". Kata ini biasa dipakai untuk menggambarkan raja yang sedang memiliki masalah pribadi, namun mampu mengendalikan dirinya sehingga dia tentap dapat menjalankan roda pemerintahan. Ternyata Orang Kristen diharapkan dapat memiliki karakter ini. Kualitas karakter seperti ini penting untuk menciptakan sebuah komunitas yang baik.

\section{PENUTUP}

Buah Roh merupakan karunia Roh Kudus. Roh Kudus memberikan Buah Roh untuk menyelaraskan kehidupan orang Percaya dengan Kristus. Ada sembilan rasa buah Roh. Kesembilan rasa buah Roh tersebut memiliki relasi yang erat dalam kehidupan manusia, baik itu hubungannya dengan Allah, hubungannya dengan sesama manusia dan diri sendiri. Melalui buah Roh inilah manusia dapat menjadi saksi dan berkat bagi orang lain. Melalui Buah Roh inilah nama Tuhan akan dipermuliakan dalam kehidupan orang Percaya. 


\section{Daftar Pustaka}

.... (2010). Alkitab, Jakarta: LAI.

Dellistone F. W. (1986). The Power Of Simbol, London: SCM Press.

Duyverman, M.E. (2011). Pembingbing Ke Dalam Perjanjian Baru, Jakarta: BPK. Gunung Mulia.

Enns, Paul. (2006). The Moody Hanbook Of Thelogy,Malang: Literatur SAAT

\section{Pustaka Online}

https://www.gotquestions.org/Indonesia/buah-Roh.html, online Januari 2016

Dictionary of Irish Architects 1720-1940. Irish Architectural Archive. Diakses tanggal 13 February 2013.

https://id.wikipedia.org/wiki/Buah_Roh_Kudus Diakses Januari 2016

Rick Renner, Sparkling Gems from the Greek, diakses Januari 2016

Morgan, Elisa. Naked Fruit: Getting Honest about the Fruit of the Spirit. Revell, 2004. ISBN 978-0-8007-1873-2

Longman, Robert Jr. "Self-Control." Web: 19 Oct 2010

http://rec.or.id/article_448_Buah-buah-Roh-(Galatia-5:22-26), Online Januari 2016 